\title{
Novel ecosystems created by coal mines in central Queensland's Bowen Basin
}

\author{
Peter D Erskine* and Andrew T Fletcher
}

\begin{abstract}
Introduction: Open-cut coal mining began in central Queensland's Bowen Basin approximately 50 years ago. Over this period of time, mine rehabilitators have used a variety of tree, shrub, and groundcover species to create 'novel ecosystems' to stabilise soils and provide vegetative cover for pre-supposed final end-land uses. We examine post-mining rehabilitation from multiple soil and vegetation monitoring activities in the Bowen Basin to assess the similarity of landforms, plant composition, and trends in plant diversity compared to unmined reference communities.

Methods: Rehabilitated spoil dumps and reference sites were assessed using soil and vegetation data contained in compliance monitoring reports from Goonyella Riverside, Moura, Oaky Creek, Rolleston, and Blackwater mines. Slopes, soil chemistry, and plant species mixes of rehabilitation aged from 2 to 22 years were compared to selected reference communities.

Results: Mines in this region have generally proposed one of two post-rehabilitation end-land uses: either pasture for cattle grazing or reconstructed native communities which potentially provide native fauna habitat. Landform data from a selection of these mine sites suggest that when their rehabilitation was compared to nearby reference sites median slope values were between 2.5 and 7 times steeper and soil pH, electrical conductivity, and phosphorus levels were significantly higher. The steeply sloped landforms, poor soil characteristics, depauperate native species pool, and uniform presence of exotic pasture grasses in the rehabilitation indicate that most of these newly created ecosystems should not be used for cattle grazing and also have few natural values.

Conclusions: Legislative and community expectations have changed progressively over time and, although much of the rehabilitation is currently dominated by an assemblage of exotic buffel grass (Cenchrus ciliaris) and Acacia spp., recent environmental authorities suggest these 'novel ecosystems' will be judged against native reference sites. Upon completion of mining activities the resilience of these new ecosystems to drought, fire, and grazing will need to be demonstrated prior to lease relinquishment.
\end{abstract}

Keywords: Coal mining; Completion criteria; Environmental conditions; Novel ecosystems

\section{Introduction}

The $80,000 \mathrm{~km}^{2}$ Bowen Basin geological formation contains Australia's largest and most lucrative coal reserves. Coal in this area was formed during the Early Permian to Middle Triassic (Geoscience Australia 2013) with coal seams up to $16 \mathrm{~m}$ thick. This resource has produced many millions of tonnes of thermal and metallurgical coal over several decades and exploitation continues today. Due to the surface proximity of coal seams, mining has predominantly been open-cut which involves

\footnotetext{
*Correspondence: p.erskine@uq.edu.au

Centre for Mined Land Rehabilitation, The University of Queensland, Brisbane QLD 4072, Australia
}

removing large volumes of overlying strata (referred to as spoil) to rapidly and completely extract economic coal seams at depths up to $200 \mathrm{~m}$. The Bowen Basin underlies a large region near the central east coast of Australia (Figure 1). Coincidentally, clearing for cattle grazing has fragmented the region's contiguous native ecosystems and coal mining continues to contribute to this fragmentation. Much of the vegetation in this area, originally dominated by Brigalow trees (Acacia harpophylla) from which the Brigalow Belt bioregion derived its name, was cleared for pasture following the Queensland Government's Brigalow and Other Lands Development Act, 1962 (Bailey 1984; Nix 1994). Techniques for removing

\section{穴 Springer}

(c) 2013 Erskine and Fletcher; licensee Springer. This is an open access article distributed under the terms of the Creative Commons Attribution License (http://creativecommons.org/licenses/by/2.0), which permits unrestricted use, distribution, and reproduction in any medium, provided the original work is properly cited. 


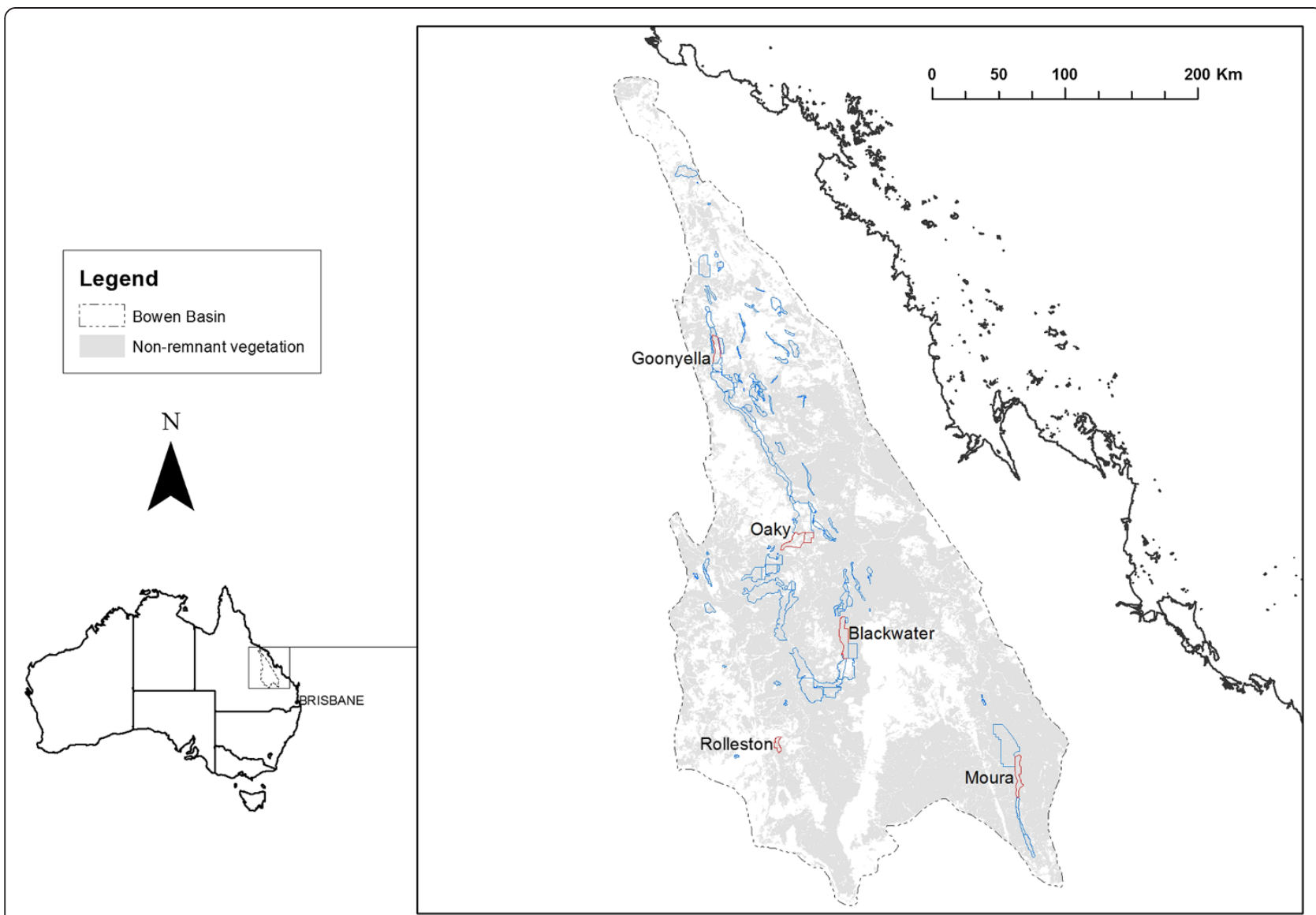

Figure 1 The location and extent of the Bowen Basin, mines where data obtained (outlined in red), other coal mine lease areas (in blue), and non-remnant vegetation in the region.

these ecosystems included repeated 'pulling' with bulldozers and chains, followed by hot fires which resulted in little or no remnant vegetation surviving. The 'success' of the Act means that all of the Brigalow dominated ecosystems in Queensland are listed as endangered under the Vegetation Management Act, 1999 (Butler 2007). Across the region a number of buffel grass (Cenchrus ciliaris) varieties were subsequently introduced to improve pasture yields and this invasive grass species is now a common feature in the landscape (Marshall et al. 2012). Altogether, these activities represent unmistakable large-scale drivers of change toward the ecological form and function of the entire biogeographic region.

In spite of these considerable long-term anthropogenic disturbance factors, extractive industries such as mining still often undertake to return affected landscapes to their pre-disturbance condition and these claims have been used to allow access to coal reserves. However, it is not clear whether these conditions can be met due to the size and severity of the mining disturbances (Doley et al. 2012; Doley and Audet 2013). Queensland mines operate in a largely self-regulatory environment without specific or standardised prescriptions for mine rehabilitation. Each
Bowen Basin coal mine operates with an individually negotiated environmental licence called an Environmental Authority (EA) outlining operating conditions to avoid, reduce, and/or mitigate environmental impacts. As a result, licence conditions for rehabilitation outcomes in EAs often use general ecological terms that may be interpreted as grossly simplified biological/ecological criteria. For instance, part of the EA process requires development of a rehabilitation monitoring and management plan to record the status of rehabilitation and manage long-term environmental results of rehabilitation. The targets for these internal rehabilitation completion criteria are often based on apparent achievements in existing areas. The following two rehabilitation completion goals are commonly found in Bowen Basin coal mine EAs (DEHP 2013):

Areas rehabilitated to native ecosystem must achieve a self-sustaining native ecosystem with species composition and distribution similar to a reference site or another suitable alternative;

Where reasonable and practicable, areas of the site where grazing is nominated as the post-mine land use must be seeded with mixtures of native grass species endemic to the area. 
Available theories underlying the practice of ecological restoration would suggest that reference sites could be used to identify suitable end goals (SER 2004). Indeed, the EAs take this into account when they agree to the goals for desirable ecosystems. However, reference sites are rarely considered in the construction and design of rehabilitated landforms, therefore a high level of caution should applied when attempting to compare these types of ecosystems. Hence, latest attitudes (cf. Shackelford et al. 2013) would suggest that the restoration goals need to move beyond just having a comparable species composition to particular reference sites and should focus on ecosystem function and stability.

In this study, we examine post-mining rehabilitation from multiple soil and vegetation monitoring activities in the Bowen Basin that are used to assess ecological performance and development following coal mining. A new point of reference is the determination of the degree to which the rehabilitated landscapes are natural (restored to the extent of its historic succession trajectory or pre-disturbance fidelity), hybrid (containing characteristics of the natural/historic landscapes, but also novel attributes), or even novel (containing new assembly of abiotic and biotic attributes resulting in a stable alternative ecological form). As suggested by Hobbs et al. (2006), this natural-novel ecosystems paradigm represents a highly useful approach for setting appropriate rehabilitation goals in relation to post-disturbance site conditions as opposed to using idealised or aspirational criteria based on adjacent/remnant reference communities. Therefore our approach focused on aspects of rehabilitation landform design, soil properties, and plant composition across a number of mine sites to address whether these rehabilitation sites resemble near/ natural ecosystems or whether alternative landforms and species selection result in the development of novel ecosystems that may function more effectively in such an extensively engineered post-mining landscape.

\section{Methods}

\section{Bioregional description}

Much of the Bowen Basin was covered by Brigalow communities; however, other common ecosystems in the region include: Mitchell (Astrebla lappacea) and Bluegrass (Dichanthium spp.) grasslands on clay plains; semievergreen vine thickets on hillslopes and sheltered areas; ironbark (Eucalyptus crebra and E. melanophloia) woodlands on ridges; and Poplar box (E. populnea) woodlands on alluvial and undulating clay plains (Neldner 1984). Major soil types over coal measures within the mine leases are summarised in Table 1 from datasets made available by the Queensland Government (2013a). Over $50 \%$ of the soils within the mine lease areas in the Bowen Basin are vertosols. This soil type can occur as
Table 1 Soils types within the mine lease boundaries in the Bowen Basin (derived from Queensland Government 2013a)

\begin{tabular}{lcc}
\hline Soil & \multicolumn{2}{c}{ Coal mine leases in the Bowen Basin } \\
\cline { 2 - 3 } & Area (ha) & Total mine leases area (\%) \\
\hline Chromosols & 16,502 & 4 \\
Kandosols & 47,580 & 10 \\
Rudosols & 4,302 & 1 \\
Sodosols & 141,750 & 32 \\
Vertosols & 236,592 & 53 \\
\hline
\end{tabular}

gilgai (hummocky mounds), which are often cracking, have high soil fertility, and good water holding capacity (Queensland Government 2013b). Another 30\% of soils are sodosols, which contain high levels of sodium, have low nutrients, are dispersive, and prone to erosion (Table 1).

\section{Mine rehabilitation activities}

The topsoils (broadly listed in Table 1) are generally removed prior to mining and stored for variable time periods (months to decades) before returning as a homogenous veneer when rehabilitation is carried out. Either draglines or trucks and shovels are used to remove the spoil overlying the coal seams and then this material is dumped immediately adjacent to the active pit to minimise costs (see Figure 2). As a result, rehabilitation generally begins at the back of the spoil dump and progresses in the same direction as the pit, as the mine face moves forward (Figure 2). Spoil dumps are generally surrounded by mine pits, ramps (that trucks use to access the mine pits), and haul roads (as illustrated in Figure 2) resulting in islands of rehabilitation. A variety of methods for rehabilitation have been applied over decades. Numerous combinations of gross land form, topsoil placement, native and introduced species mixes, fertilisation, and irrigation have been applied (Williams 2001). However, mine rehabilitation practices in the Bowen Basin generally take place in the following order: spoil recontouring; construction of drains; placement of 10 to $30 \mathrm{~cm}$ of topsoil; contour ripping; and direct seeding of grass and tree species. These rehabilitation efforts now cover tens of thousands of hectares in the Bowen Basin.

\section{Environmental monitoring}

Soil and vegetation monitoring data from rehabilitated spoil dumps and reference sites are routinely collected for compliance reporting purposes on a semi-annual basis. For this paper we utilise data contained in reports from Goonyella Riverside mine (CMLR 2000), Moura mine (CMLR 2002), Oaky Creek mine (CMLR 2003), Rolleston mine (Landline 2012), and Blackwater mine 


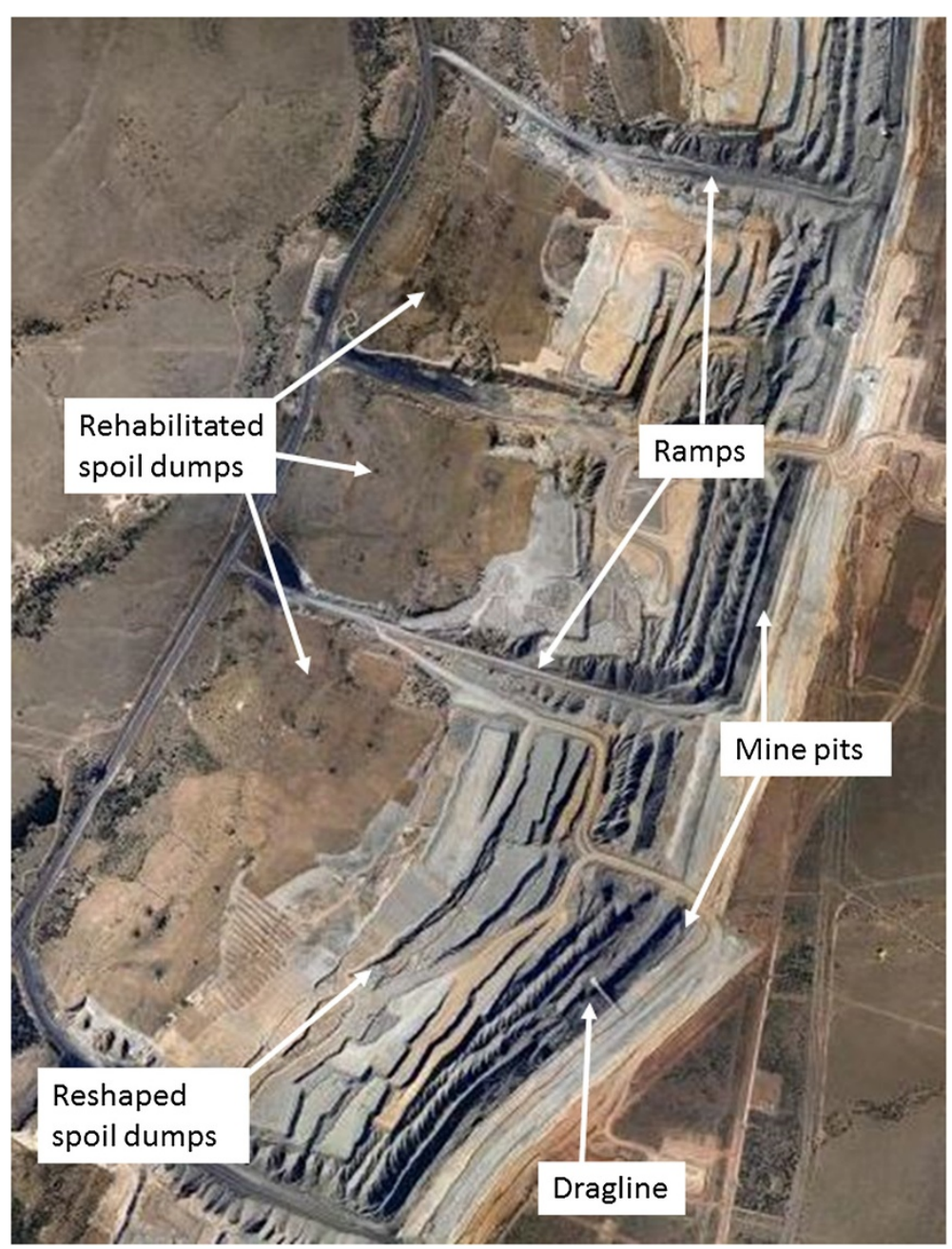

Figure 2 An overview of Blackwater coal mine operations and the location of rehabilitated spoil dumps in relation to the mine pits (image from AAM).

(Tuck et al. 2006). The locations of these mines are in Figure 1 and examples of site rehabilitation at Oaky Creek, Blackwater, and Goonyella Riverside are illustrated in Figure 3. Methods of data collection differ among sites and years (Table 2). Across sites different sized plots have been used (i.e. species diversity was measured in $20 \mathrm{~m} \times 20 \mathrm{~m}$ plots at Moura and $10 \mathrm{~m} \times$ $100 \mathrm{~m}$ plots at Blackwater). Data in these reports also included vegetation plots measured yearly (i.e. Goonyella in 1998, 1999, and 2000) and over a 3-year period (i.e. Blackwater in 2003 and 2006). Topsoil depth sampled (either 0 to $5 \mathrm{~cm}$ or 0 to $10 \mathrm{~cm}$, see Table 2) and soil analytical methods also varied between sites. Electrical conductivity (EC) and $\mathrm{pH}$ of soils at both Oaky Creek and Goonyella mines were determined on 1:5 soil:water extracts of samples following Rayment and Higginson (1992). At Goonyella Riverside available phosphorus (Avail P) was determined colorimetrically following $0.5 \mathrm{M} \mathrm{NaHCO}_{3}$ (1:10) extraction, while total phosphorus
(Total P) at Oaky was measured using inductively coupled plasma optical emission spectrometry (ICPOES). Due to differences in plot size, sample frequency and soil analysis cross-site comparisons are difficult. Nevertheless, for the purposes of this paper data have been selected from sites where direct comparison can be made or from an individual site to illustrate general trends for mine rehabilitation in the region.

\section{Statistical analysis}

Due to the lack of guidelines for ecological and biophysical assessments of coal mine rehabilitation in Queensland, the quality and quantity of monitoring data varies considerably between sites and over time. Our analysis includes monitoring data from a range of sites, companies, and timeframes. Therefore, assessment methods change and may appear incomplete, yet this is common for monitoring programs where different scientists and restricted access to rehabilitated areas can alter data 


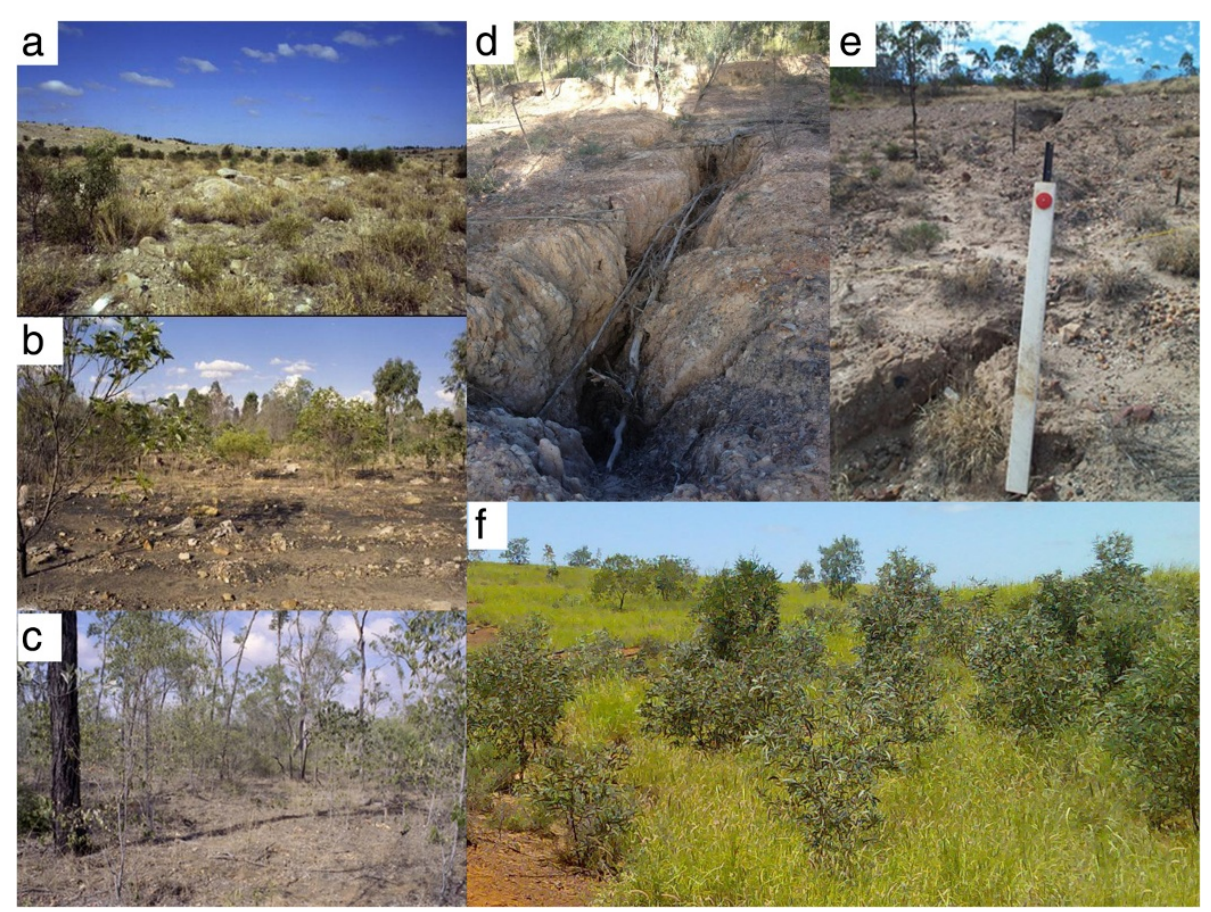

Figure 3 Images of Oaky Creek and Goonyella Riverside rehabilitation. (a) Oaky Creek mine rehabilitation after 2 years, (b) 10-year-old rehabilitation at Oaky Creek mine, (c) Poplar box (Eucalyptus populnea) woodland reference site at Oaky Creek with Eremophila mitchellii in the understory, (d) rehabilitation with extensive tunnel and gulley erosion, (e) young gulley erosion in mine rehabilitation, and (f) Brigalow (Acacia harpophylla) tube stock trial at Goonyella Riverside mine.

collection. Data from rehabilitation and reference sites were generally compared at individual mines in a single sampling year or from a chronosequence of rehabilitation sites as a 'space-for-time' substitution to draw successional inferences. The different years and methods of data collection precluded most cross-mine site comparisons.

Reference ecosystems at each site were generally selected to represent the most diverse plant communities within the local area and were predominantly inside the mine lease (CMLR 2000, 2002, 2003; Landline 2012; Tuck et al. 2006). Differences in slopes for rehabilitated dumps and reference sites at Goonyella Riverside, Rolleston, and Blackwater mines were compared at each site using analysis of variance (ANOVA) with a Tukey honest significant difference (HSD) for unequal $\mathrm{N}$ post-hoc test (Statisica 64, StatSoft, Inc, Tulsa, OK, USA). Soil chemistry for rehabilitation and reference sites at Goonyella Riverside and Oaky Creek coal mines were also examined using

Table 2 Number, years, age, and size of the vegetation plots assessed, soil sampling depth, slopes assessed, and data source

\begin{tabular}{|c|c|c|c|c|c|c|c|}
\hline Mine & $\begin{array}{c}\text { Number of } \\
\text { vegetation } \\
\text { plots reported }\end{array}$ & $\begin{array}{c}\text { Years } \\
\text { sampled }\end{array}$ & $\begin{array}{c}\text { Rehabilitation } \\
\text { age when last } \\
\text { assessed (years) }\end{array}$ & $\begin{array}{c}\text { Plot } \\
\text { size }(\mathrm{m})\end{array}$ & $\begin{array}{l}\text { Topsoil } \\
\text { sample } \\
\text { depth }\end{array}$ & $\begin{array}{l}\text { Number } \\
\text { of slopes } \\
\text { assessed }\end{array}$ & $\begin{array}{l}\text { Origin } \\
\text { of data }\end{array}$ \\
\hline \multirow[t]{2}{*}{ Blackwater } & 5 rehabilitation & 2003,2006 & 14 to 16 & $10 \times 100$ & & 22 rehabilitation & Tuck et al. 2006 \\
\hline & 4 reference & 2006 & & & & 8 reference & \\
\hline \multirow[t]{2}{*}{ Goonyella Riverside } & 20 rehabilitation & 1998, 1999, 2000 & 3 to 24 & $20 \times 20$ & 0 to $5 \mathrm{~cm}$ & 26 rehabilitation & CMLR 2000 \\
\hline & 11 reference & 2000 & & & & 11 reference & \\
\hline \multirow[t]{2}{*}{ Moura } & 6 reference & 2002 & 2 to 22 & $20 \times 20$ & & & CMLR 2002 \\
\hline & 6 rehabilitation & 2002 & & & & & \\
\hline \multirow[t]{2}{*}{ Oaky Creek } & 16 rehabilitation & 2003 & 2 to 10 & $20 \times 50$ & 0 to $10 \mathrm{~cm}$ & & CMLR 2003 \\
\hline & 11 reference & 2003 & & & & & \\
\hline \multirow[t]{2}{*}{ Rolleston } & 3 rehabilitation & 2010, 2011, 2012 & 4 to 5 & $50 \times 3$ & & 11 rehabilitation & Landline 2012 \\
\hline & & & & & & 8 reference & \\
\hline
\end{tabular}


the same statistical methods, but only for within-site differences. Plant species diversity was assessed using Plymouth Routines in Multivariate Ecological Research version six (PRIMER 6) to conduct non-parametric multidimensional scaling (nMDS) and hierarchical cluster analysis of plant composition at Oaky Creek, Blackwater, and Moura mine sites. nMDS ordinations were based on a Bray-Curtis similarity matrix generated from presence/absence species data of different aged sites over time, compared to nearby reference sites. Minchin (1987) compared a number of statistical methods and suggested that nMDS is the most robust method to assess compositional differences between sites. A group-average cluster analysis was conducted with the Bray-Curtis similarity matrix and, based on the generated cluster dendrogram, a 25\% similarity threshold was superimposed on the nMDS ordinations for the rehabilitated and reference sites.

Data on species richness at 20 different Goonyella Riverside mine rehabilitation areas over a 3-year period (Table 2) was assessed using regression analysis to demonstrate changes in plant species numbers over time. Trends in groundcover species at three young rehabilitated sites at Rolleston coal mine were assessed from ten $\left(0.25 \mathrm{~m}^{2}\right)$ quadrats placed along the central transect of a single $50 \mathrm{~m} \times 3 \mathrm{~m}$ plot. The mean proportional density of grass and forb species within these quadrats was graphed over time to illustrate the effects of different soil and fertiliser application on the types of species that persist or dominate a grassland site.

\section{Results}

Most of the mine sites examined in this paper had vertosol soils (Goonyella, Blackwater, Moura, and Rolleston) but several mines also had extensive areas of highly dispersive sodosols (Blackwater, Oaky, and Moura) (cf. Burgess 2003). As local topsoils are utilised for rehabilitation their chemical and physical properties are important to the long-term stability of the landforms. Soils at Goonyella mine (Table 3 ) varied in a range of chemical properties in comparison to rehabilitated sites and reference areas. Electrical conductivity, $\mathrm{pH}$, and available phosphorus are significantly higher $(P<0.05)$ in rehabilitated soils compared to reference sites. Similar significant differences between $\mathrm{pH}, \mathrm{EC}$, and total phosphorus at Oaky Creek mine (Table 3) suggest that there are consistent differences between replaced soils and those found at selected reference sites. Additionally, the variability of rehabilitated soil parameters are generally greater than of the reference sites. This is likely the result of the rehabilitation process that involves mixing multiple soil horizons, the application of fertiliser to aid plant growth, and incorporation of spoil during ripping.

Table 4 demonstrates that the constructed landforms of mine rehabilitation have consistently significantly steeper slopes than reference sites. Median values for rehabilitated slopes ranged between 6\% (Rolleston) and $12 \%$ (Blackwater) steeper than the selected reference sites, but these slopes are not steep when compared to rocky hillslopes in the wider region (particularly Blackdown Tableland National Park).

Plant species compositional differences between mine rehabilitation areas at Moura, Oaky Creek, and Blackwater and their selected reference sites are illustrated in Figure 4. In each graph, rehabilitated sites are dissimilar to reference sites at a young age and this difference persists over time. Moura mine (Figure 4a) had species that were only found on rehabilitated areas, including A. salicina, Enchylaena tomentosa, and Corymbia maculata, while they shared Malvastrum americanum (exotic) and E. crebra with several reference sites. Three species, Eremophila mitchellii, Hibiscus sturtii, and A. decora, were observed only in the native reference sites. At Oaky mine C. ciliaris (exotic) and Salsola kali were the only common species found across rehabilitation and reference sites. Species solely found in reference communities included E. populena, E. mitchellii, A. harpophylla, and Alphitonia excelsa, while other species found exclusively in rehabilitation included $A$. bancroftiorum, $A$. victoriae, C. citriodora, E. camaldulensis, and Chloris gayana (exotic). The presence/absence of these species contributed much of the dissimilarity observed in Figure 4b. At Blackwater the differences observed in Figure 4c were

Table 3 Comparison of mean soil chemistry parameters between rehabilitation and reference sites at Oaky Creek and Goonyella Riverside coal mines

\begin{tabular}{|c|c|c|c|c|c|c|c|c|c|}
\hline \multirow[t]{2}{*}{ Mine } & \multirow[t]{2}{*}{ Site type } & \multicolumn{8}{|c|}{ Soil value } \\
\hline & & Mean pH & $\mathrm{pH} \mathrm{SD}$ & $\begin{array}{c}\text { Mean EC } \\
(\mathrm{dS} / \mathrm{m})\end{array}$ & EC SD & $\begin{array}{c}\text { Mean Total } \\
P(\mathrm{mg} / \mathrm{kg})\end{array}$ & $\begin{array}{l}\text { Total } \\
\text { P SD }\end{array}$ & $\begin{array}{c}\text { Mean Avail } \\
\text { P (mg/kg) }\end{array}$ & $\begin{array}{l}\text { Avail } \\
\text { P SD }\end{array}$ \\
\hline \multirow[t]{2}{*}{ Oaky Creek } & Rehabilitation & $8.36^{\mathrm{a}}$ & 0.66 & $0.66^{\mathrm{a}}$ & 0.85 & $314^{a}$ & 102 & & \\
\hline & Reference & $6.73^{b}$ & 1.92 & $0.04^{b}$ & 0.03 & $233^{b}$ & 100 & & \\
\hline \multirow[t]{2}{*}{ Goonyella Riverside } & Rehabilitation & $7.93^{\mathrm{a}}$ & 0.89 & $0.24^{\mathrm{a}}$ & 0.35 & & & $7.70^{a}$ & 4.98 \\
\hline & Reference & $5.55^{\mathrm{b}}$ & 0.64 & $0.06^{b}$ & 0.01 & & & $1.35^{b}$ & 1.06 \\
\hline
\end{tabular}

Superscript letters next to mean values denote that they are significantly different $(P<0.05)$ at each mine site using ANOVA and a Tukey HSD for unequal N posthoc test. ANOVA, analysis of variance; Avail P, available phosphorus; EC, electrical conductivity; HSD, honest significant difference; SD, standard deviation; Total P, total phosphorus. 


\begin{tabular}{llcccc} 
Table 4 Reported slopes of mine rehabilitation and \\
selected reference sites \\
\hline Mine & Site type & \multicolumn{5}{c}{ Slope } \\
\cline { 2 - 6 } & & Number & $\begin{array}{c}\text { Mean } \\
\text { (\%) }\end{array}$ & SD & $\begin{array}{c}\text { Median } \\
\text { (\%) }\end{array}$ \\
\hline Blackwater & Rehabilitation & 22 & $13^{\mathrm{a}}$ & 4.2 & 13 \\
& Reference & 8 & $2^{\mathrm{b}}$ & 1.02 & 2 \\
Goonyella Riverside & Rehabilitation & 26 & $12^{\mathrm{a}}$ & 6.8 & 14 \\
& Reference & 11 & $3^{\mathrm{b}}$ & 2.5 & 2 \\
Rolleston & Rehabilitation & 11 & $9^{\mathrm{a}}$ & 6.4 & 10 \\
& Reference & 8 & $6^{\mathrm{a}}$ & 5.3 & 4 \\
\hline
\end{tabular}

Superscript letters next to mean slope values denote that they are significantly different $(P<0.05)$ across sites using ANOVA and a Tukey HSD for unequal $\mathrm{N}$ post-hoc test. ANOVA, analysis of variance; HSD, honest significant difference; $\mathrm{SD}$, standard deviation.

the result of $A$. harpophylla, Alectryon diversifolius, $E$. Mitchellii, and E. thozetiana present only in reference sites and Stylosanthes scabra, Melinis repens, and A. macradenia restricted to rehabilitation sites. Two species occurred across all surveyed Blackwater sites, the native ruby saltbush $E$. tomentosa and the exotic C. ciliaris (Buffel grass). The maximum similarity of a rehabilitated site to a reference site at Blackwater mine was $21 \%$. Some trees and shrubs found only in rehabilitation at these mine sites include species that are native to the region, but were not found in the reference sites selected for comparison. Thus, some of the observed differences in species composition in Figure 4 also reflect the novelty of the seed mixes used to create ecosystems that occupy rehabilitated mine sites.

Buffel grass was relatively common throughout rehabilitation and most native sites examined in the Bowen Basin. The abundance of this species may be a contributing factor to the marked decline observed in species diversity over time at Goonyella Riverside mine rehabilitation (Figure 5). Buffel was observed in all rehabilitation plots at Goonyella Riverside mine and generally dominated the groundcover, competing strongly with other species for water, nutrients, and light. A downward trend in native species richness was observed in the data from Moura mine $(\mathrm{r}=-0.65$, data not shown) and has also been previously reported at Blackwater rehabilitation (Erskine et al. 2007).

A series of graphs (Figure 6) illustrate changes in buffel grass cover following the application or the omission of fertiliser in rehabilitation areas targeting grassland at Rolleston mine. The highly competitive buffel rapidly dominated groundcover proportion when fertiliser was applied during the rehabilitation process, at the expense of all other species such as $M$. americanum (exotic) (Figure 6a) and the native grass species Dicanthium sericeum and Heteropogon contortus (Figure 6b). At a trial site which omitted fertiliser and used direct placement of fresh topsoil, the native grass species $D$. sericeum and Bothriochloa bladhii both increase in cover over the same time period with a general decline in buffel grass (Figure 6c). Across all three sites there was no observed erosion and each site had close to $100 \%$ vegetative cover across all years (Landline 2012). These results indicate that standard, agricultural type fertiliser applications are unlikely to be appropriate for development of native vegetation communities in this landscape.

\section{Discussion}

Coal mining in the Bowen Basin has massively altered the structure of this landscape, particularly over the course of mounding large quantities of spoil material across tens of thousands of hectares where there was once relatively flat country. Some of the notable dilemmas faced by rehabilitation practitioners working in this environment are that the soils and spoils of the region are often dispersive and require a rapid vegetation cover to ensure that they are protected from erosion forces, particularly heavy rainfall events during summer (Carroll and Tucker 2000; Arnold et al. 2013). The use of fast growing exotic species as vegetation cover, such as buffel and Rhodes grasses (C. gayana), combined with high dosage applications of N/P fertiliser at most sites in the Bowen Basin (Roe et al. 1996) has ensured that these species provide some level of erosion protection at the expense of slower growing native species, and, of course, to the detriment of mine closure expectations that require re-instatement of natural/native ecosystems. Even with these measures, uniformly and steeply sloped landforms, poorer soil chemical properties, combined with the unknown traits of the underlying spoil material, make the stability of most of these landforms uncertain. As erosion has proven to be a challenging parameter to measure consistently (Evans et al. 2000a, b) this analysis could not effectively examine efforts that have been attempted at different mine sites. Nevertheless, gully, sheet, tunnel, and pipe erosion were regularly documented (also illustrated in Figures 3d,e) and the consequences of active erosion regularly requires maintenance at most sites (CMLR 2000, 2002, 2003; Tuck et al. 2006).

To address the question of "whether rehabilitation sites resemble natural ecosystems or whether alternative landforms and species selection result in the development of novel ecosystems?' this paper examined a range of landform and species parameters at a selection of mine sites. In particular, measures of slope and soil chemistry all suggested that rehabilitated systems were structurally different to selected reference sites and the observed plant communities on mined land did not closely resemble any native reference site. While some native species that coexist among reference sites were often accounted for in rehabilitated sites, there were also 


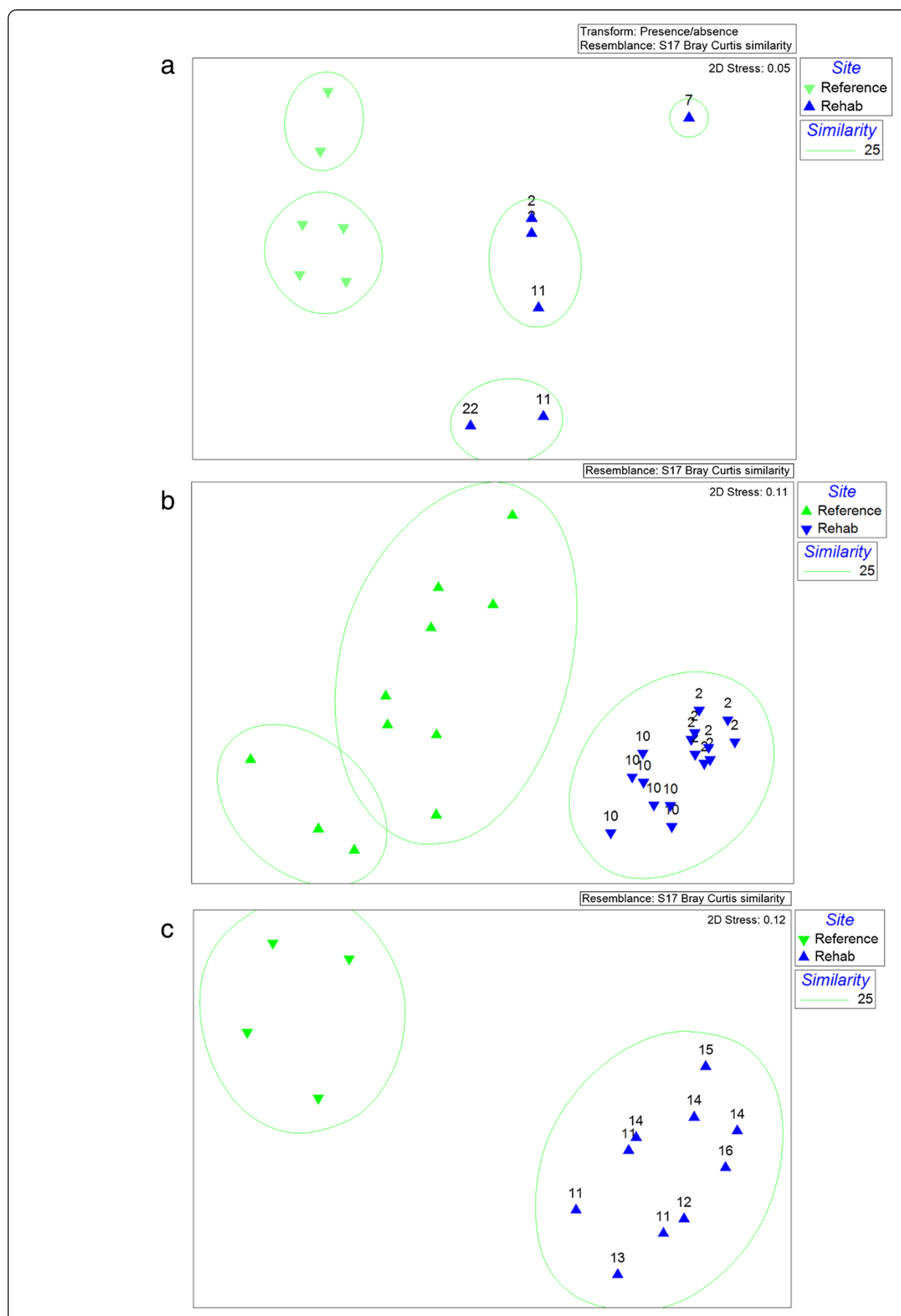

Figure 4 Plant species composition differences between coal mine rehabilitation and reference sites. (a) Moura mine for differently aged sites, (b) Oaky Creek mine for sites that were either 2 or 10 years old, and (c) Blackwater mine from two sampling times. 


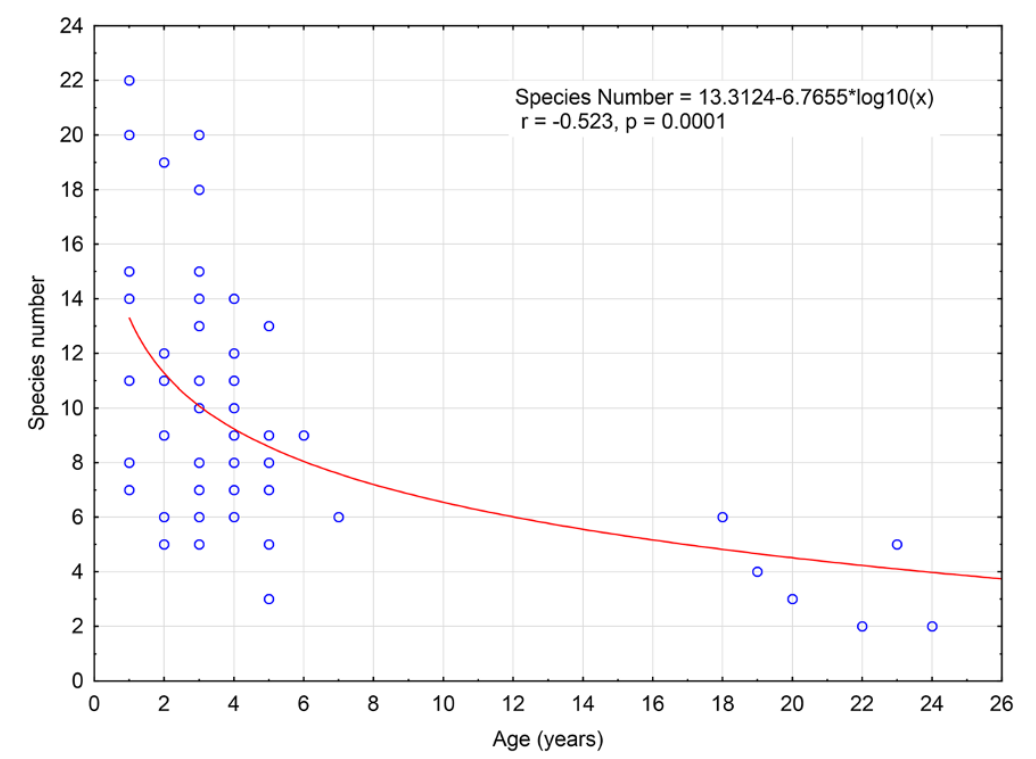

Figure 5 Observed decline in species diversity for 20 rehabilitation sites sampled three times from 1998 and 2000 at Goonyella Riverside mine.

novel mixtures/assemblages of species such as $A$. bancroftiorum, A. victoriae, C. citriodora, and E. camaldulensis at Blackwater rehabilitation, i.e. species that are broadly native to the region but do not co-occur in any described reference ecosystem. A common shrub species in the region, E. mitchellii, was present in all selected reference sites at Blackwater, Moura, and Oaky Creek mines but was not observed in rehabilitation plots. In practice, this species, as well as the foremost Brigalow (A. harpophylla), could be more successfully established on these mine sites if viable tube stock (see Figure 3f) or cuttings were used more extensively rather than attempting to rely upon direct seeding techniques (Ensol and Emmerton 2006). Yet, without effective land management and planning that focuses on the establishment of native species and ecosystem processes, i.e. rather than solely on the early development of groundcover with species that are known to arrest ecological succession (Butler and Fairfax 2003; D'Antonio and Chambers 2006), rehabilitation may not achieve the necessary native flora to provide appropriate and desired habitat for native fauna. Due to the highly erosive nature of rehabilitated mine spoil some of the suggested management tools to increase native grass species using selective grazing of exotic grasses by ungulates (Firn et al. 2013; Friedel et al. 2011) are likely to lead to landform instability and further degrade these young ecosystems. However, the trends observed at Rolleston mine (where buffel grass was found to decline in the absence of fertiliser) support suggestions by Gibson-Roy et al. (2010) that scalping of soils and removing nutrients are key components to native Australian grass species restoration. In this particular mine's EA, the mine closure plan has undertaken to restore a Queensland Bluegrass (D. sericeum) community and the trial data presented suggests that using a reference site to determine the success of their rehabilitation would be appropriate. At all other sites examined, there appears to be little evidence that reference sites have been used to guide rehabilitation practices and in these cases Seastedt et al. (2008) would suggest that novel and native deficient ecosystems should be expected to develop.

Evidently, based on these outcomes, mining disturbances resulting in novel/non-natural landform elements and rehabilitation practices incorporating exotic and/or novel assemblages of native species appear to have contributed to novel ecosystems, i.e. systems that are irreversibly different to any natural/pre-disturbance conditions both in terms of biotic and abiotic composition. In special cases where hybrid sites may bear some semblance of natural systems, genuine restoration could be achieved if further rehabilitation inputs are allocated commensurate to changing divergent landforms or mitigating exotic species. This can only be addressed if the coal mining industry shifts its basic rehabilitation expectations and associated practices, particularly in regards to recontouring spoils (Carroll and Tucker 2000) and filling pits, which happen to represent expensive and extensive ground-works. However, there is no apparent desire to change from a large-scale, low-cost production model (Mudd 2010). This model allows coal mines in the Bowen Basin to leave residual voids and these voids, in turn, contribute to steeper landforms that require ongoing maintenance. Risk aversion of regulators and increasing awareness of environmental liabilities mean 

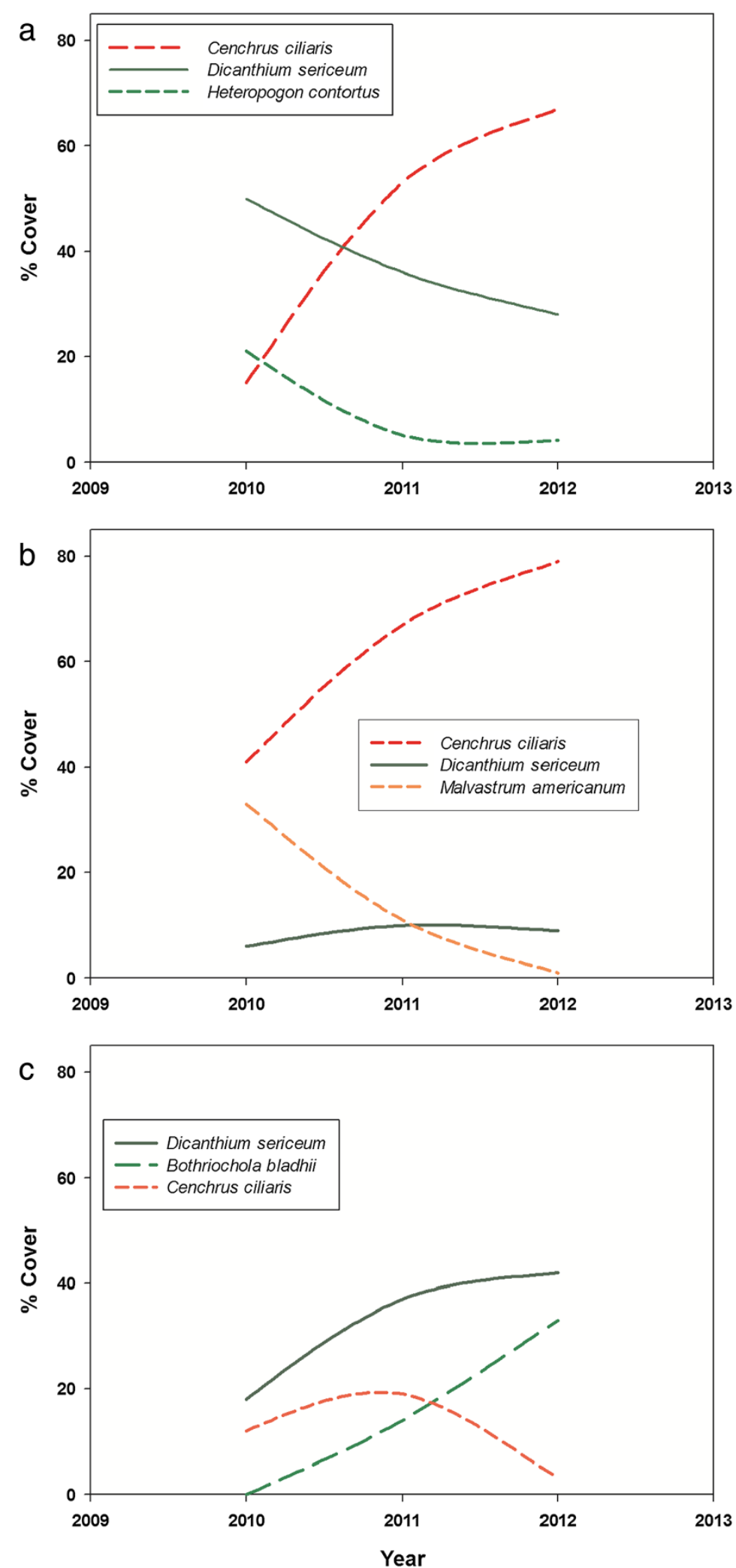

Figure 6 Changes in groundcover species abundance at Rolleston mine. (a) 2007 rehabilitated spoil covered with $0.2 \mathrm{~m}$ black soil plus application of NPK fertiliser at $100 \mathrm{~kg} / \mathrm{ha}$, (b) 2008 rehabilitated spoil covered with $0.2 \mathrm{~m}$ black soil plus application of NPK fertiliser at $100 \mathrm{~kg} / \mathrm{ha}$, and (c) a 2007 trial site covered in directly placed 0.3 m black soil where buffel was omitted from seed mix and no fertiliser was added. 
that compelling evidence will be required to demonstrate that these post-mine landforms represent minimal liability to subsequent land users before formal relinquishment will be possible. One alternative to substantial spoil recontouring (predominantly levelling the newly mounded landscape) would be to rock armour slopes, but this has not been widely used in coal mines due to the lack of knowledge about rock resources and an absence of selective handling of material removed to access coal seams (George et al. 1986). The approach of restraining dispersive spoil with rock reinforced slopes, combined with the application of native species adapted to scree slopes or drought tolerant species from more arid areas (Ensol and Emmerton 2006; Shackelford et al. 2013) would provide alternative landscape and ecosystem scenarios that would be more stable in the longer term.

Given that open-cut coal mining unavoidably leads to the destruction of all vegetation and often the underlying soils, possible proactive changes in their landform design and rehabilitation approach must be viewed with scepticism given the common intention to leave voids, nonnatural landscape attributes (e.g. waste rock dumps), and other artifacts of mining unrehabilitated. Perhaps Hughes et al.'s (2012) suggestion that these large-scale rehabilitation efforts, conducted in human-derived, remote areas with high management costs, should really only be expected to develop non-polluting novel ecosystems and that this is, unfortunately, the best that can be hoped for at mine closure unless significantly greater influx of funds and rehabilitation efforts can be allocated in order to achieve the desired ecological outcome.

\section{Conclusions}

Our findings indicate that, where rehabilitation objectives aim to return disturbed lands following coal mining to a self-sustaining native community, these environments are unlikely to be as biologically diverse as existing regional ecosystems because of an altered soil profile and hydrology, a limited selection of native seed species, and exotic species competition. If mines continue to use topsoil with seed banks dominated by aggressive and opportunistic exotic species (such as buffel grass) and add fertiliser, very few native species will survive over the longer term due to an altered competitive equilibrium. To retain native grasses rehabilitation needs to use directly placed topsoil, rather than soil stored for years, and minimise fertiliser supplementation, particularly avoiding the application of large quantities of phosphorus. For native species biodiversity, planting seedlings rather than single time direct seeding may be required where framework species, such as Eucalyptus spp. or A. harpophylla, should form part of rehabilitated ecosystems. Finally, where native ecosystems are selected as a rehabilitation goal, persistence of constructed landforms and plant communities will require a different landscape design and drought tolerant species sourced from naturally sloped, shallow depauperate soil conditions.

Despite these practical considerations, a larger question remains: should society accept the current rehabilitated landforms and vegetation types as new novel regional ecosystems or demand that mining companies (as primary benefactors of the exploitation of nonrenewable resources) achieve higher quality ecosystems with more native species that are both resilient and functional into the distant future? Unless the ecosystems created can demonstrate some utility to future land users, public perception will remain that mining companies need to manage their leases in perpetuity. While the approach taken in this paper may appear atypical in the field of ecology and restoration science (especially when compared to carefully formalised field trials and ecological assessments), we consider that our findings provide a unique insight into ongoing large-scale mining activities and the associated challenges faced by rehabilitation practitioners. Indeed, the post-disturbance conditions typically associated with open-cut mining (as described here) appear to satisfy the definition of novel ecosystems (or, at the very least, hybrid ecosystems). However, coal mine rehabilitation in Queensland currently does not incorporate suitable assessments of the degree to which sites are novel or the novel management strategies that may be required to insure the highest standard of ecological stewardship where novelty is an inevitable outcome of industrial disturbance. In this regard, a first-step should be acknowledging that coal mining often results in many irreversible changes to the landscape and that rehabilitation outcomes will likely differ considerably compared to the pre-disturbance or historical ecosystem.

\section{Abbreviations}

ANOVA: Analysis of variance; Avail P: Available phosphorus; CMLR: Centre for mined land rehabilitation; EA: Environmental authority; DEHP: Department of environment and heritage protection; EC: Electrical conductivity; HSD: Honest significant difference; ICP-OES: Inductively coupled plasma optical emission spectrometry; nMDS: Non-parametric multidimensional scaling; PRIMER 6:

Plymouth routines in multivariate ecological research version six; SER: Society for ecological restoration; SD: Standard deviation; Total P: Total phosphorus.

\section{Competing interests}

Both authors conduct research projects funded by coal mining companies and the Australian Coal Association Research Program.

\section{Authors' contributions}

PE conceived and designed the study, collated data, and drafted the manuscript. AF conceived a number of key plinths of the document, redrafted, and critically revised the content. Both authors read and approved the final manuscript.

\section{Acknowledgements}

The authors would like to thank the monitoring teams that collect annual data on rehabilitated coal mines, as it is often treacherous work that requires active avoidance of hidden sink holes and gulley erosion. The authors would 
also like to thank the anonymous reviewers and the 'Novel Ecosystem' special issue editors for improving this manuscript.

Received: 13 May 2013 Accepted: 3 December 2013 Published: 20 December 2013

\section{References}

Arnold S, Audet P, Doley D, Baumgartl T (2013) Hydropedology and ecohydrology of the Brigalow Belt, Australia: Opportunities for ecosystem rehabilitation in semiarid environments. Vadose Zone J. doi:10.2136/ vzj2013.03.0052

Bailey A (1984) The Brigalow Belt of Australia. Royal Society of Queensland, Brisbane Burgess JW (2003) Land Resource Assessment of the Windeyers Hill Area, IsaacConnors and Mackenzie River Catchments, Central Queensland. Land Resources Bulletin QNRM02189, vol 1. Queensland Department of Natural Resources and Mines, Brisbane

Butler DW (2007) Recovery Plan for the Brigalow (A. harpophylla dominant and co-dominant) Endangered Ecological Community. Report to the Department of the Environment and Water Resources, Canberra. Queensland National Parks and Wildlife Service, Brisbane

Butler DW, Fairfax RJ (2003) Buffel grass and fire in a Gidgee and Brigalow woodland: A case study from central Queensland. Ecol Manage Rest 4:120-125

Carroll C, Tucker A (2000) Effects of pasture cover on soil erosion and water quality on central Queensland coal mine rehabilitation. Trop Grass 34:254-262

CMLR (2002) Rehabilitation Monitoring at Moura Mine: An Assessment of Vegetation, Habitat, Soil and Erosion Parameters, Centre for Mined Land Rehabilitation. University of Queensland, Brisbane

CMLR (2003) Long Term Monitoring at Oaky Creek Coal Mine, Centre for Mined Land Rehabilitation. University of Queensland, Brisbane

CMLR (Centre for Mined Land Rehabilitation) (2000) Goonyella Riverside Mine Rehabilitation Monitoring 2000, Centre for Mined Land Rehabilitation. University of Queensland, Brisbane

D'Antonio CM, Chambers JC (2006) Using Ecological Theory to Manage or Restore Ecosystems Affected by Invasive Plant Species. In: Falk DA, Palmer MA, Zedler JB (ed) Foundations of Restoration Ecology. Island Press, Washington DC, pp 260-279

DEHP (Department of Environment and Heritage Protection) (2013) Public register of environmental authorities. http://www.ehp.qld.gov.au/land/ mining/index.html

Doley D, Audet P (2013) Adopting novel ecosystems as suitable rehabilitation alternatives for former mine sites. Ecol Process 2:22

Doley D, Audet P, Mulligan D (2012) Examining the Australian context for postmined land rehabilitation: Reconciling a paradigm for the development of natural and novel ecosystems among post-disturbance landscapes. Agric Ecol Env 163:85-93

Ensol J, Emmerton B (2006) Specialist Woody Species for Bowen Basin Coal Mine Rehabilitation and Native Ecosystem Re-establishment. ACARP Report C13038, Brisbane

Erskine PD, Mulligan DR, Olsen MF, Kirsch B, Roe P (2007) Completion Criteria for Rehabilitated Forest Ecosystems on Mined Land - Should They be Based on Unmined Reference Sites? In: Fourie AB, Tibbett M (ed) Mine Closure 2007, Santiago. Australian Centre for Geomechanics, The University of Western Australia, Nedlands, pp 211-216

Evans KG, Willgoose GR (2000) Post-mining landform evolution modelling: 2. Effects of vegetation and surface ripping. Earth Surf Process Land 25(8):803-823

Evans KG, Willgoose GR, Saynor MJ, Riley SJ (2000) Post-mining landform evolution modelling. I. Derivation of sediment transport model and rainfall-runoff model parameters. Earth Surf Processes Land 25(7):743-763

Firn J, Price JN, Whalley RDB (2013) Using strategically applied grazing to manage invasive alien plants in novel grasslands. Ecol Process 2:26

Friedel M, Grice A, Marshall N, van Klinken R (2011) Reducing contention amongst organisations dealing with commercially valuable but invasive plants: The case of buffel grass. Env Sci Pol 14(8):1205-1218

George H, Meech J, Workman L (1986) Towards reducing the physical environmental impact of North American surface coal mines; a review of potential selective overburden handling techniques. Min Sci Technol 3(2):81-94

Geoscience Australia (2013) Bowen Basin. http://www.ga.gov.au/energy/provincesedimentary-basin-geology/petroleum/offshore-northwest-australia/browse.htm

Gibson-Roy P, Moore G, Delpratt J, Gardner J (2010) Expanding horizons for herbaceous ecosystem restoration: the Grassy Groundcover Restoration Project. Ecol Manage Rest 11:176-186
Hobbs RJ, Arico S, Aronson J, Baron JS, Bridgewater P, Cramer VA, Epstein PR, Ewel JJ, Klink CA, Lugo AE, Norton D, Ojima D, Richardson DM, Sanderson EW, Valladares F, Vila M, Zamora R, Zobel M (2006) Novel ecosystems: theoretical and management aspects of the new ecological world order. Global Ecol Biogeogr 15:1-7

Hughes FMR, Adams WM, Stroh PA (2012) When is open-endedness desirable in restoration projects? Rest Ecol 20(3):291-295

Landline (2012) Rehabilitation monitoring report 2012. Unpublished report for Rolleston Coal, Atherton, Qld, p 85

Marshall VM, Lewis MM, Ostendorf B (2012) Buffel grass (Cenchrus ciliaris) as an invader and threat to biodiversity in arid environments: A review. J Arid Environ 78:1-12

Minchin PR (1987) An evaluation of relative robustness of techniques for ecological ordinations. Vegetatio 69:89-107

Mudd GM (2010) The environmental sustainability of mining in Australia: key mega-trends and looming constraints. Resources Policy 35(2):98-115

Neldner VJ (1984) Vegetation Survey of Queensland (South Central Queensland). Department of Primary Industries, Brisbane, Australia

Nix HA (1994) The Brigalow. In: Dovers S (ed) Australian Environmental History: Essays and Cases. Oxford University Press, Melbourne, pp 198-233

Queensland Government (2013a). http://dds.information.qld.gov.au/DDS/Search.aspx

Queensland Government (2013b). http://www.derm.qld.gov.au/science/slr/ queensland_soils.html

Rayment GE, Higginson FR (1992) Australian Laboratory Handbook of Soil and Water Chemical Methods. Inkata Press, Melbourne

Roe PA, Mulligan DR, Bell LC (1996) Environmental Management of Coal Mines in the Bowen Basin, Central Queensland. In: Mulligan DR (ed) Environmental Management in the Australian Minerals and Energy Industries. Principles and practices. University of NSW Press, Sydney, pp 290-315

Seastedt TR, Hobbs RJ, Suding KN (2008) Management of novel ecosystems - are novel approaches required? Front Ecol Environ 6:547-553

SER (Society for Ecological Restoration) (2004) SER International Primer on Ecological Restoration. Society for Ecological Restoration International Science \& Policy Working Group. http://www.ser.org/resources/resourcesdetail-view/ser-international-primer-on-ecological-restoration

Shackelford N, Hobbs RJ, Burgar JM, Erickson TE, Fontaine JB, Laliberté EL, Ramalho CE, Perring MP, Standish RJ (2013) Primed for change: developing ecological restoration for the 21st century. Restor Ecol 21:297-304

Tuck G, Baker PW, Olsen MF (2006) BMA Blackwater mine rehabilitation monitoring 2006. Unpublished report prepared for BMA Blackwater mine, Brisbane, Qld, p 111

Williams D (2001) Risk Management Strategies for the Surrender of Open Cut Dragline Spoil Pile Areas. Australian Coal Association Research Program Report C8039. The University of Queensland, Brisbane

\section{doi:10.1186/2192-1709-2-33}

Cite this article as: Erskine and Fletcher: Novel ecosystems created by coal mines in central Queensland's Bowen Basin. Ecological Processes 2013 2:33.

\section{Submit your manuscript to a SpringerOpen ${ }^{\circ}$ journal and benefit from:}

- Convenient online submission

- Rigorous peer review

- Immediate publication on acceptance

- Open access: articles freely available online

- High visibility within the field

- Retaining the copyright to your article

Submit your next manuscript at springeropen.com 